\title{
Effect of Addition of Black Cumin Seed Oil (Nigella sativa) as a Source of Omega-6 on Cork Albumin Powder (Channa Striata) for Wound Closure
}

\author{
Dwi Inayatur Rohmah*, Eddy Suprayitno** \\ *Department of Fisheries Technology \\ Faculty of Fisheries and marine science \\ Brawijaya university Indonesia \\ dwiinayatur@student.ub.ac.id \\ **Department of Fisheries Technology \\ Faculty of Fisheries and marine science \\ Brawijaya university Indonesia \\ eddysuprayitno@ub.ac.id
}

DOI: 10.29322/IJSRP.10.07.2020.p10371

http://dx.doi.org/10.29322/IJSRP.10.07.2020.p10371

\begin{abstract}
Albumin powder which is processed through vacuum drying life it does not smell, the storing period is longer, and could be used anytime and anywhere. The formation of albumin in the form of powder is also easily absorbed in the body especially helps in wound care. The addition of black cumin seed oil to albumin powder as a source of omega 6 because black cumin seed oil contains active ingredients thymoquinone, saponins and flavonoids which have anti-microbial, antioxidant and cell regenerating effects. Provision of albumin powder in animals using the sonde method. The results of Phase 1 research showed differences in the concentration of black cumin seed oil affect the quality of albumin powder, namely omega 6, protein content, fat content, ash content, and yield. The best albumin powder was obtained at 12\% black cumin seed oil concentration with the following results omega 6 was $1.92 \%$, protein content was $11.25 \%$, fat content was $5.24 \%$, ash content was $0.97 \%$, and yield was $60.37 \%$. The highest fatty acid profile test results showed that Linoleic Acid was $1.92 \%$ and the lowest Cis-8,11,14-Eicosetrienoic Acid, C20: 3n6 was 0.002\%. Then proceed to Phase 2 of the study, namely the testing of fatty acid profiles, zinc levels and mice try animals obtained observations on day 3, day 5, and day 7 showed the best concentration of albumin powder treatment $12 \%$ experienced a process of wound closure. wound character $65 \%$ on the 7 th day.
\end{abstract}

Index Terms- albumin powder, black cumin seed oil, wound closure.

\section{INTRODUCTION}

Cork fish (Channa striata) has a high nutritional content and a variety of functions for health one of which can improve the process of wound recovery (Asikin and Kusumaningrum, 2018). Besides albumin, the wound cover on several components, namely the role of collagen, omega 3 fatty acids and omega 6 (Nicodemus et al., 2014). Black cumin seed oil (Nigella sativa) as a source of omega 6 contains the active ingredient thymoquinone which has anti-microbial and antioxidant effects that can accelerate wound closure. Giving black cumin seed oil to wounds can increase wound tissue regeneration (Hibono, 2017). The active substances contained in black cumin beside thymoquinone are saponins and flavonoids. In addition to regenerating cells, saponins have the ability to protect wounds, whereas flavonoids can be used as an antiseptic (Puspitasari et al., 2016). Collagen is a key component in the phase of wound management. The collagen characteristics that attach cells to form new connected tissues (Siregar and Suprayitno, 2019). The collagen used is collagen from grouper skin because grouper has the best collagen content (Suprayitno, 2019). Source of omega 3 fatty acids from flaxseed oil (Linum usitatissimum).

Cork fish albumin is usually consumed in liquid and fishy form so not everyone likes it. To overcome this problem, a way to dry it is to produce albumin powder extract or albumin powder (Hidayat and Suprayitno, 2019). Albumin powder which is processed through drying can produce a non-fishy taste, a pungent odor, a long shelf life and can be used anytime and anywhere. The formation of albumin which consists of powder is also easily absorbed in the body which is more important in wound care (Firlianty, 2016).

\section{MATERIALS AND METHODS}

\subsection{Material}


The research material used consisted of raw materials for the production of albumin extract, namely cork fish, materials for making collagen, namely grouper skin, $\mathrm{NaOH}$, astic acid and aquades. The material for making albumin powder is albumin extract derived from the extraction of cork fish, collagen, black cumin seed oil as a source of omega 6 , flaxseed oil as a source of omega 3 and the coating material namely sorbitol and dextrin.

This research method is an experimental method. This research was conducted in two stages, namely stage 1 research and stage 2 research. Research 1 aims to obtain the optimal concentration of black cumin seed oil which is added to the production of albumin powder so that the best powder quality is obtained for the second stage research. While the second phase research aims to see the process of wound closure in animals using albumin powder with the best quality compared to negative control and negative control.

\subsubsection{Process Extraction Albumin}

The making of albumin extract begins with the preparation of raw materials ie cork fish is turned off by being hit on the head, then the fish is weeded, dipped and then diced and washed with running water. Furthermore, cork fish weighed 250 grams, then put into steam at a temperature of $70^{\circ} \mathrm{C}$ for 30 minutes. After that the cork fish meat is filtered and the filtrate is taken. Cork fish extract is ready to use.

\subsubsection{Process Collagen}

Collagen manufacturing is done by preparing grouper skin that has been removed from scales and remaining flesh attached. Grouper skin is cut $1 \times 1 \mathrm{~cm}$ and then soaked with $0.1 \mathrm{M} \mathrm{NaOH}$ for 24 hours with a ratio of skin and solution of 1:10, then grouper skin is neutralized with aquades. Furthermore, soaked with acetic acid in the ratio of 1:10 for 24 hours and then filtered and taken the filtrate. Then the precipitation is done with $\mathrm{NaCl} 0.9 \mathrm{M}$ for 24 hours. After 24 hours, centrifugation was carried out at $3500 \mathrm{rpm}$ for 20 minutes then dialysis with $0.5 \mathrm{M}$ acetic acid in a ratio of 1:10. Then inserted into the cellophane membrane. After that the cellophane membrane was immersed in $0.1 \mathrm{M}$ acetic acid solution for 6 hours. Furthermore, soaked with distilled water to neutral $\mathrm{pH}$. After that, collagen is ready to use.

\subsubsection{Process Albumin Powder}

The making of albumin powder is $180 \mathrm{ml}$ cork fish extract albumin added with $6 \%$ sorbitol and $80 \%$ dextrin. Then added black cumin seed oil concentrations of $8 \%, 10 \%$, and $12 \%$. Subsequently added $0.6 \%$ collagen, $1.5 \%$ flaxseed oil then homogenized with a $2000 \mathrm{rpm}$ homogenizer for 15 minutes. The resulting mixture is poured into a baking dish and dried with vacuum drying. After the sample is dried, blend until smooth and sieved with a 60 mesh sieve. Albumin powder was analyzed in omega 6, protein content, fat content, water content, ash content, yield and organoleptic

\section{RESULT AND DISCUSSION}

\subsection{Omega 6}

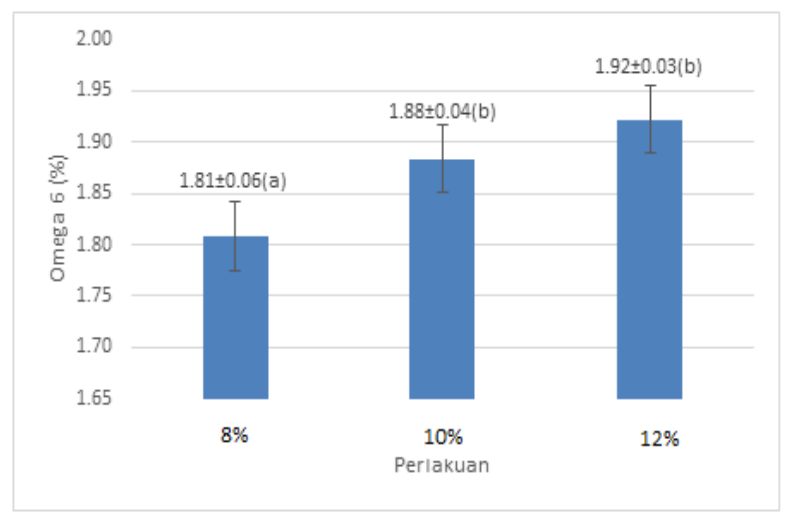

Figure 1. The Result of Omega 6

Omega 6 albumin powder with different concentrations of black cumin seed oil produces different omega 6 values. At $8 \%$ black cumin seed oil concentration of $1.82 \%, 10 \%$ concentration of $1.88 \%$, and $12 \%$ concentration of $1.92 \%$. The highest omega 6 value is shown at a concentration of $12 \%$ which is equal to $1.92 \%$, while the lowest omega 6 at an concentration of $8 \%$ is $1.82 \%$. The omega 6 black cumin seed oil value has decreased due to the heating process when drying albumin powder. According to Sipayung et al. (2015), one cause of damage to fat is oxidation. The oxidation process is not determined by the size of the amount of fat in the material so that even small amounts of fat-containing material are easily subjected to oxidation. 


\subsection{Protein Content}

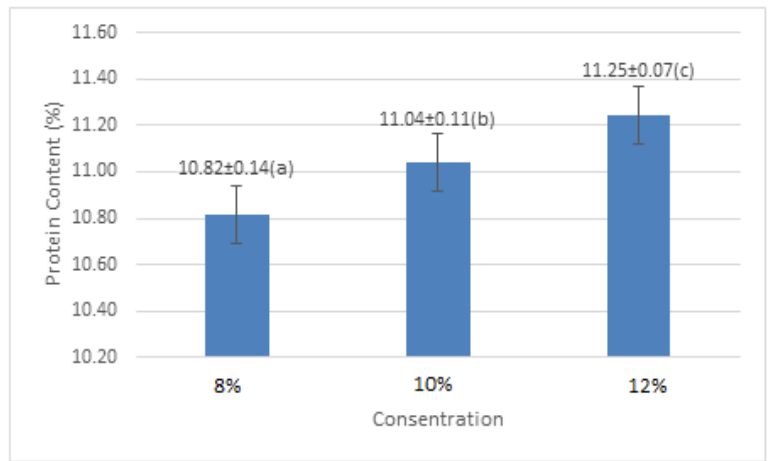

Figure 2. The Result of Protein Content

The value of $8 \%$ black cumin seed oil concentration produced a protein content of $10.82 \%$, a concentration of $10 \%$ at $11.04 \%$, and a concentration of $12 \%$ at $11.25 \%$. The highest protein content results in the concentration of black cumin seed oil $12 \%$ by $11.25 \%$ and the value of the lowest protein content in the concentration of black cumin seed oil $8 \%$ is $10.82 \%$. Protein content produced in the manufacture of powder increases with increasing concentration of black cumin seed oil that is given in the manufacture of powder. This is because black cumin seed oil contains high protein which is equal to $22.7 \%$.

\subsection{Water Content}

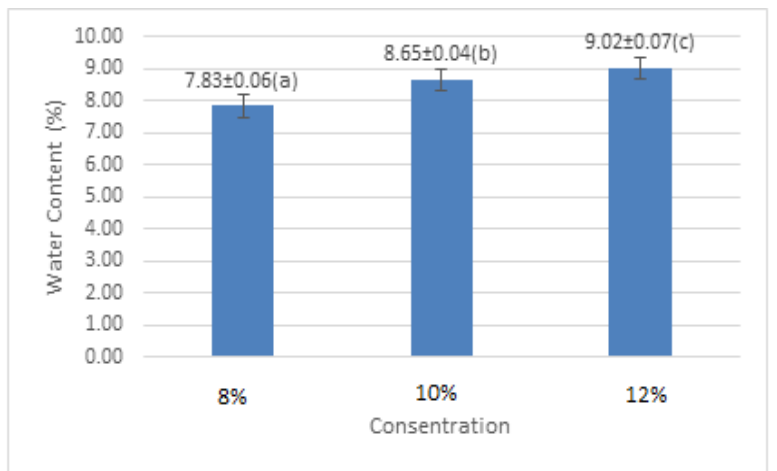

Figure 3. The Result of Water Content

The value of $8 \%$ black cumin seed oil concentration produced a moisture content of $7.83 \%$, a concentration of $10 \%$ at $8.65 \%$, and a concentration of $12 \%$ at $9.02 \%$. The highest value of water content in black cumin seed oil concentration of $12 \%$ was $9.02 \%$ and the lowest water content value was in the concentration of black cumin seed oil $8 \%$ of $7.83 \%$. The water content in the resulting albumin powder showed an increase along with the increased concentration of black cumin seed oil given.

\subsection{Fat Content}

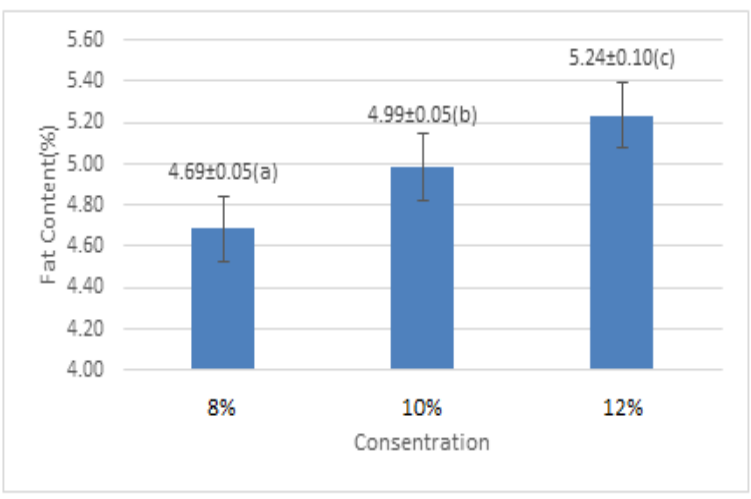

This publication is licensed under Creative Commons Attribution CC BY. 
The fat content of albumin powder at the concentration of black cumin seed oil was $4.69 \%$, the concentration of $10 \%$ was $4.99 \%$, and the concentration of $12 \%$ was $5.24 \%$. The highest value of fat content in black cumin seed oil concentration is $12 \%$ by $5.24 \%$, and the lowest value of fat content in black cumin seed oil concentration is $8 \%$ by $4.69 \%$. It can be concluded that the higher the concentration of cumin seed oil, the greater the fat content produced.

\subsection{Ash Content}

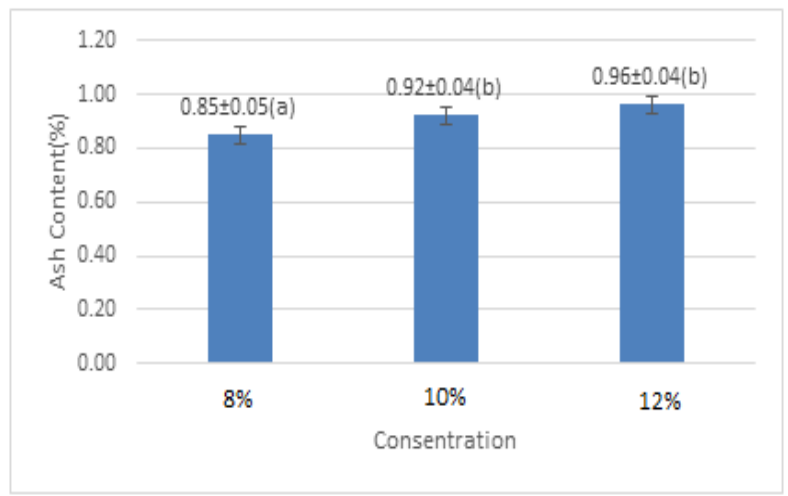

Figure 5. The Result of Ash Content

Ash content contained in the concentration of $8 \%$ black cumin seed oil produced ash value of $0.85 \%, 10 \%$ concentration of $0.91 \%$, and $12 \%$ concentration of $0.97 \%$. The highest ash content value in the concentration of black cumin seed oil is $12 \%$ by $0.97 \%$, and the lowest ash content value in the concentration of black cumin seed oil is $8 \%$ by $0.85 \%$. The ash content in the albumin powder comes from omega 3 source oil and omega 6 source oil added.

\subsection{Yield}

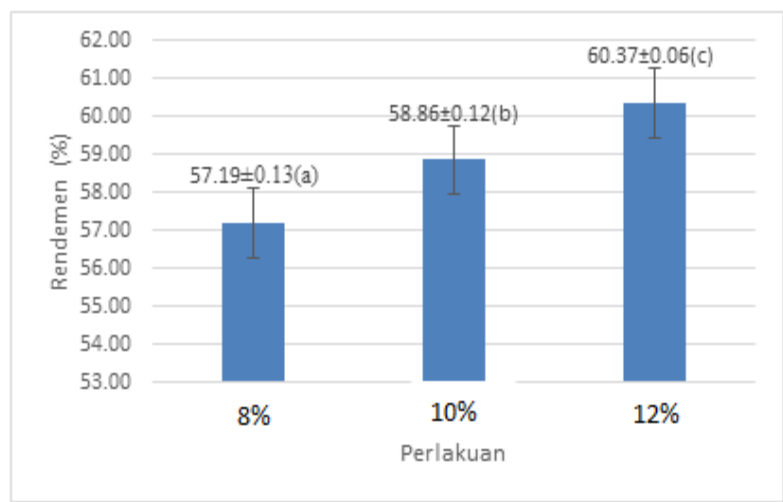

Figure 6. The Result of Yield

The results of the yield at $8 \%$ black cumin seed oil yield yields $57.19 \%, 10 \%$ concentration at $58.86 \%$, and $12 \%$ concentration at $60.37 \%$. The highest yield at a concentration of $12 \%$ was $60.37 \%$ and the lowest yield at a concentration of $8 \%$ was $57.19 \%$. The higher the concentration of black cumin oil given will increase the volume the higher the yield produced.

\subsection{Organoleptic}




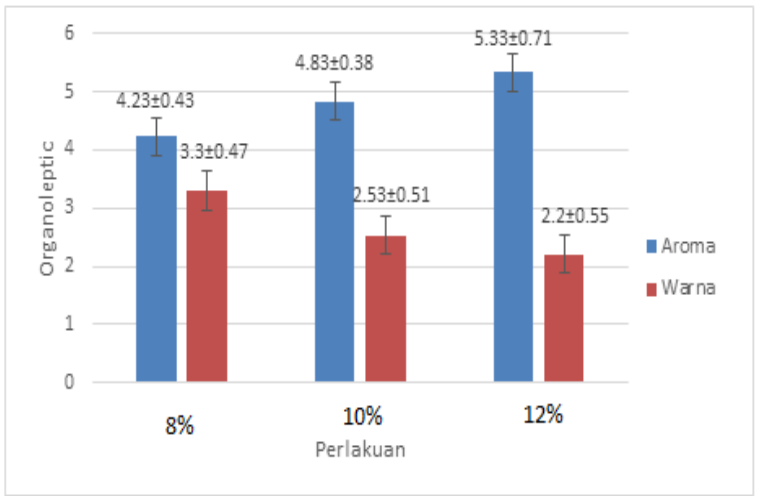

Figure 7. The result of Organoleptic

Organoleptic assessment of albumin powder with different concentrations shows differences. At $8 \%$ black cumin seed oil concentration, the value of color parameter shows a value of 3.30, a concentration of $10 \%$ at 2.53 , and a concentration of $12 \%$ at 2.20 . Whereas in the treatment of black cumin seed oil concentration with a concentration of $8 \%$ the aroma parameter was 4.23 , a concentration of $10 \%$ was 4.83 , and a concentration of $12 \%$ was 5.33. In the color parameter, the highest value was obtained from the concentration of black cumin seed oil at $3 \%$ by 3.30 and the lowest value from the concentration of black cumin seed oil at a concentration of $12 \%$ by 2.20 . The highest value in the color parameter indicates that panelists dislike the color produced by albumin powder with the addition of black cumin seed oil because it tends to be too brown. As for the aroma parameter, the highest value was obtained from the concentration of black cumin seed oil at $12 \%$ by 5.33 and the lowest value of the concentration of black cumin seed oil at $8 \%$ by 4.23 . The highest value on the aroma parameter indicates that the panelists liked the color produced from albumin powder with the addition of black cumin seed oil because the resulting aroma was not fishy and pungent.

\subsection{Animal Testing}

After knowing the optimal concentration of black cumin seed oil for the production of best quality albumin powder, which is $12 \%$ concentration which is then tested on animals to find out the effect of albumin powder on wound closure, further tests are analysis of albumin powder fatty acid profile, and zinc content test. Albumin powder with the best concentration of $12 \%$ was then compared with negative control and positive control. Mice were injured with a wound length of $2 \mathrm{~cm}$. The process of wound closure was measured for 7 days with observation on the 3rd day of the 5th day and 7th day. Giving albumin powder using the sonde method.

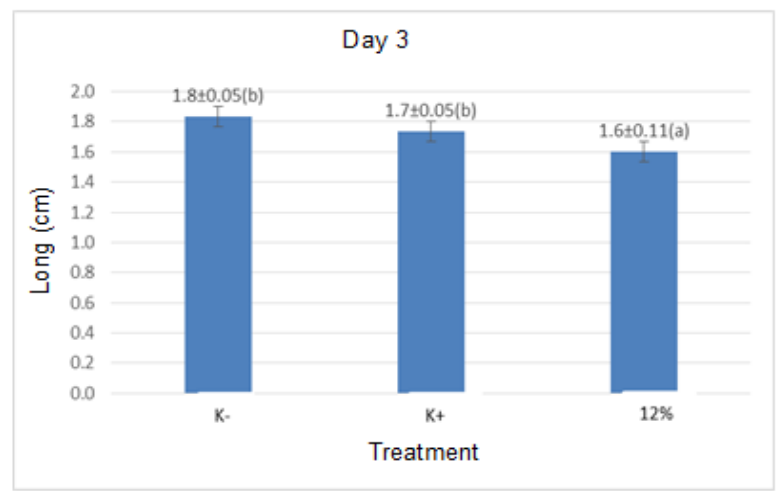

Figure 8. The Result of Day 3

On the 3rd day different treatments showed different results of wound closure. The negative control treatment showed an average wound length of $1.8 \mathrm{~cm}$, a positive control treatment of $1.7 \mathrm{~cm}$, and a $12 \%$ albumin concentration powder treatment of $1.6 \mathrm{~cm}$. The fastest wound closure on day 3 was obtained at $12 \%$ albumin powder concentration treatment of $1.6 \mathrm{~cm}$, while the longest wound closure was at negative control treatment of $1.8 \mathrm{~cm}$. This can be interpreted that the wound closure process on the treatment on the $3 \mathrm{rd}$ day was $30 \%$. 


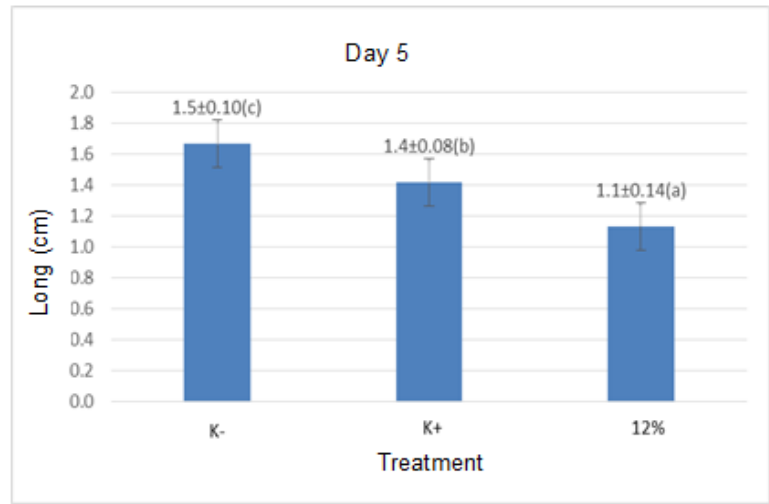

Figure 9. The Result of Day 5

Different treatments show different results of wound closure on the 5th day. The negative control treatment showed an average wound length of $1.5 \mathrm{~cm}$, a positive control treatment of $1.4 \mathrm{~cm}$, and a $12 \%$ albumin concentration powder treatment of $1.1 \mathrm{~cm}$. The fastest wound closure on day 5 was obtained by albumin powder treatment with a concentration of $12 \%$, which was $1.1 \mathrm{~cm}$, while the longest wound closure was negative control treatment at $1.5 \mathrm{~cm}$. This can be interpreted that the process of wound closure at the best treatment on the 5 th day was $45 \%$.

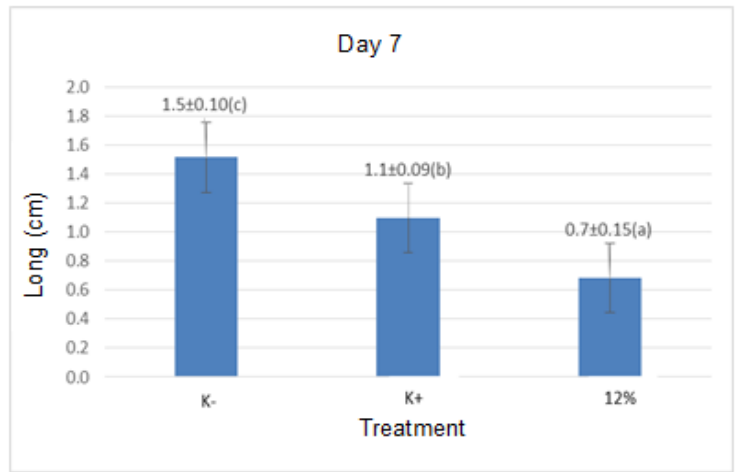

Figure 10. The Result of Day 7

The negative control treatment showed an average wound length of $1.5 \mathrm{~cm}$, a positive control treatment of $1.1 \mathrm{~cm}$, and a $12 \%$ albumin concentration powder treatment of $0.7 \mathrm{~cm}$. The fastest wound closure on day 7 was obtained by a $12 \%$ concentration of albumin powder treatment of $0.7 \mathrm{~cm}$, while the longest wound closure was at a negative control treatment of $1.5 \mathrm{~cm}$. This can be interpreted that the process of wound closure at the best treatment on day 7 was $65 \%$.

\subsection{Fatty Acid Profile}

\begin{tabular}{ccc}
\hline No. & Jenis Asam Lemak & Kadar (\%) \\
\hline 1. & Linoleic Acid, C18:2n6c & 1.92 \\
2. & Linolenic Acid, C18:3n3 & 0.94 \\
3. & Oleic Acid, C18:1n9c & 0.99 \\
4. & Heptadecanoic Acid, C17:0 & 0.006 \\
5. & Palmitoleic Acid, C16:1 & 0.02 \\
6. & Arachidonic Acid, C20:4n6 & 0.006 \\
7. & Cis-11,14-Eicosedienoic Acid, C20:2 & 0.07 \\
8. & Cis-4,7,10,13,16,19-Docosahexaenoic Acid, C22:6n33 & 0.01 \\
9. & rinolenic Acid, C18:3n6 & 0.94 \\
10. & Stearic Acid, C18:0 & 0.18 \\
11. & Palmitic Acid, C16:0 & 0.51 \\
12. & Myristic Acid, C14:0 & 0.01 \\
13. & Pentadecanoic Acid, C15:0 & 0.002 \\
14. & Lauric Acid, C12:0 & 0.06 \\
15. & & 0.06 \\
\hline
\end{tabular}

This publication is licensed under Creative Commons Attribution CC BY. 


Total 5.724

The highest content of fatty acids in albumin powder with black cumin seed oil concentration of $12 \%$ was Linoleic Acid of $1.92 \%$ and the lowest Cis-8,11,14-Eicosetrienoic Acid, C20: 3n6 was 0.002. The high linoleic fatty acid in albumin powder due to the use of black cumin seed oil which contains a lot of linoleic acid or omega 6. High and low fatty acids in the product can be caused by these fatty acids can not stand the heat during the drying process.

\subsection{Zinc Content}

The best concentration of $\mathrm{Zn}$ in albumin powder was $1.82 \mathrm{mg} / 100 \mathrm{~g}$. Compounds that accelerate wound healing are zinc minerals $(\mathrm{Zn})$, and unsaturated fatty acids such as omega 3, omega 6 in cork fish albumin powder can accelerate the wound closure process. Omega- 6 fatty acids found in black cumin seed oil and mineral and vitamin content are useful as nutrients in healing wound cuts on the backs of mice and stimulating the division of new cells (cell proliferation). So the addition of black cumin seed oil as a source of omega 6 and zinc influences the wound healing process.

\section{CONCLUSION}

Black cumin seed oil concentration of $12 \%$ is the optimal concentration to produce the best albumin powder. include omega 6 values of $1.92 \%$, protein content of $11.25 \%$, fat content of $5.24 \%$, ash content of $0.97 \%$, and yield of $60.37 \%$.

The results showed that giving different treatments to wounds had a significant influence on the process of wound closure. At the observations of the 3rd day, 5th day, and 7th day, the process of wound closure was $65 \%$ as good as the experimental animals treated with albumin powder on the 7th day.

\section{REFERENCES}

Asikin, A. N., dan I. Kusumaningrum. 2018. Karakteristik Ekstrak Protein Ikan Gabus Berdasarkan Ukuran Berat Ikan Asal Das Mahakam Kalimantan Timur. JPHPI. 21 (1):137-147. ISSN: 2303-2111.

Firlianty. 2016. Vacuum Drying Albumin Powder of Snakehead (Channa micropeltes) Potential for Wound Healing from Central Kalimantan, Indonesia. International Journal of Chemical Technology Research. 9 (5): 263-269. ISSN: 0974-4290.

Hibono, M. M. 2017. Pemberian Minyak Jintan Hitam (Nigella sativa) Topikal Meningkatkan Regenerasi Jaringan Luka Tikus

Diabetes Melitus. Indonesian Journal of Anti Aging Medicine. 1 (1): 25-31. ISSN 2615-5079.

Hidayat, M. I., and E. Suprayitno. 2019. The Effect of Adition of Skim Milk And Natrium Alginate to The Quality of Crude Albumin Fish Cork (Ophiocephalus striata) (Drying with Vacuum Drying). International Journal of Scientific and Research Publications. 9 (5): 202-209. ISSN: 2250-3253.

Nicodemus, M. Andrie dan S. Luliana. 2014. Uji efek penyembuhan luka sayat ekstrak ikan toman (Channa micropeltes) secara oral pada tikus putih jantan wistar. Jurnal Mahasiswa farmasi Fakultas Kedokteran UNTAN. 1(1):1-14. ISSN: 2551-9713.

Puspitasari, R., Sunyoto., Arrosyid, M. 2016. Uji Efektifitas Ekstrak Lidah Buaya (Aloe vera L.) terhadap Penyembuhan Luka Sayat pada Mencit Jantan (Mus muscullus) galur Swiis. CERATA Journal Of Pharmacy Science. 9 (1): 1-6. ISSN: 2089-1458.

Sipayung, B. S., W. F. Ma'ruf., dan E. N. Dewi. 2015. Pengaruh Senyawa Bioaktif Buah Mangrove Avicennia marina Terhadap Tingkat Oksidasi Fillet Ikan Nila Merah O. niloticus Selama Penyimpanan Dingin. Jurnal Pengolahan dan Bioteknologi Hasil Perikanan. 4 (2): 115-123. ISSN: 2442-4145.

Siregar, G.R.M. and E. Suprayitno. 2019. Amino acid composition of gelatin from Ephinephelus sp. IOSR Journal of Agriculture and veterinary Science. 12(4): 51-54. ISSN:2319-2372.

Suprayitno, E. 2019. Amino acid marshmallow profile from grouper bone gelatin. International Journal of Scientific and Research Publications. 9(11):111-113. ISSN 2250-3153. 